\title{
INSTALMENT SALE CONTRACTS IN THE DETROIT CONCILIATION COURT
}

\author{
Mary Henderson Risk*
}

Like the student of law, the student of family life has learned to rely upon individual cases for his materials, to require as complete a statement of facts as it is possible to get, and to draw conclusions as to underlying principles cautiously and with ample footnotes for exceptions. The law offers an extensive case literature; but family case histories are for the most part restricted to the records of relief organizations, whose cases are biased by their common characteristic of dependency. Most efforts to secure more representative samples have been handicapped by the tradition of privacy in family affairs.

A series of case records which are unusually valuable for the study of economic characteristics of certain families has been recently made available by the establishment of the Conciliation Division in the Common Pleas Court of the City of Detroit, Michigan. ${ }^{2}$ The principal function of the Division is to facilitate partial payments by employee debtors on judgments granted by the Court. The debtor discloses the amount of his wages, his financial condition, and the number of his dependents. The record of payments through the Conciliation Division identifies periods of employment and unemployment. Testimony at hearings on debtors' motions frequently adds valuable supplementary information. This testimony, however, is not reported by the Division and it can be had only by attending sessions of the Court.

The purpose of this article is to present a group of cases involving instalment purchase contracts which were heard in the Conciliation Division between January I8 and January 28, I935. Although these cases tend to illustrate some of the abuses to which instalment selling and financing have been subject and some of the hazards which the deferred payment system has added to family life, they are inadequate evidence upon which to base an appraisal of the system itself. Instalment selling defies nice generalizations concerning its influence as a social institution. It is but one of the many influences which impinge upon modern family life, and its consequences cannot be isolated completely from those of other forces. Also, the effect

- B.A., 1930, Wellesley. Research Assistant, Department of Remedial Loans, Russell Sage Foundation, since 1934.

'For a description of this court, see Nugent, Devices for Liquidating Small Claims in Detroit, supra, p. 259 , at p. 260 . 
of an identical set of influences upon individual families is in large degree unpredictable. Like the individuals who compose it, the family has temperament, prejudices, aptitudes, and ineptitudes, and what is one family's meat is another's poison.

The reader will recognize promptly that all of the cases presented here have other common characteristics beside the criterion by which they were selected. All cases involve defaulted contracts, since default is necessary to provide the creditor with a right of action. All cases, also, have a common locale. Plaintiffs and defendants live or do business in Detroit or its environs. Whether or not they are directly assoriated with the automobile industry, the fortunes of both parties are affected in large measure by the course of automobile production. Further, the relationships of debtor and creditor are governed in each case by Michigan law. Consequently, these cases tend to demonstrate the impact of instalment contracts upon defaulting families in a city dominated by a seasonal industry, and in a state whose garnishment law is unusually severe for the debtor.

During the period covered by our study of the Conciliation Division, hearings were held on approximately 275 cases. Many of these hearings took but a few seconds to complete and the process was so rapid that it was frequently impossible for a reporter to identify even the case numbers. In 150 hearings, however, it was possible to identify the case number and to record oral testimony. This record was then supplemented after adjournment of the court by examining the docket and the clerk's record. As far as the employment of the debtor and the nature of the debt were concerned, the hearings reported appeared to be representative of those listed on the docket.

Among our 150 cases, $7 \mathrm{x}$ involved instalment purchase contracts. Of the plaintiffs holding instalment contracts, jewelers and clothing companies were the most numerous. Automobile finance companies, furniture stores and radio shops were the next in order. Both in our sample and among all the outstanding cases on which partial payments were being made through the Division, a small number of creditors were the plaintiffs in the majority of cases.

The 25 cases presented here were selected solely because they furnished the most complete record. There has been no effort to make them representative either of kinds of creditors or of specific problems and abuses in the instalment purchase system, but by accident they are not untypical in these regards. The basis of selection tends, however, to introduce an element of bias. The hearings which produced the least verbal evidence and were disposed of in the shortest time were generally the simplest cases. Cases in which the Court paused to ask questions were generally those in which the practices of the creditor or the sincerity of the debtor were questionable. Our sample tends, therefore, to exclude cases in which the debt was acknowledged and payments were completed without difficulty.

Beyond this, the cases speak for themselves: 


\section{Case Number I.}

The plaintiff, an instalment clothing company, took a judgment for $\$ 64.50$, in September, 1932, against the defendant, an employee of an automobile manufacturing company. Except for brief periods when he was laid off, the defendant made regular payments to the plaintiff during the nine months which followed. He was still afraid of garnishment, however, and in July, I933, he arranged for partial payments through the Conciliation Division. Thereafter he made regular payments through the Division when he was employed. But he worked only part of the time during I934, and while he was laid off the plaintiff had the file released.

In January, I935, the defendant was rehired, and his wife came to Court to have his motion for partial payments reinstated. She reported that her husband's biweekly wage was $\$ 50$, and that they owed four other delinquent debts: \$ro for electricity, $\$ 5$ o to a doctor, $\$ 55$ to a department store, and $\$ 300$ for delinquent rent. She said she had eight children. Since she appeared to be about twenty-eight years old, the court questioned her truthfulness. To corroborate her statement she recalled several stories concerning her age and her children which had appeared in local newspapers. The Court remembered them.

Since the balance due on the judgment was only $\$ 6$, she arranged to eliminate the debt by two bi-weekly payments.

\section{Case Number 2.}

The plaintiffs, an industrial bank and an automobile finance company, had taken judgments against the defendant, an employee of an automobile manufacturing company. The industrial bank had taken judgment in September, r933, for \$147; and the automobile finance company in December, 1933, for $\$ 108.45$, which represented the balance claimed by the finance company as a deficiency following the repossession and sale of a used car which the defendant had bought in November, r931. The plaintiff reported the account as follows:

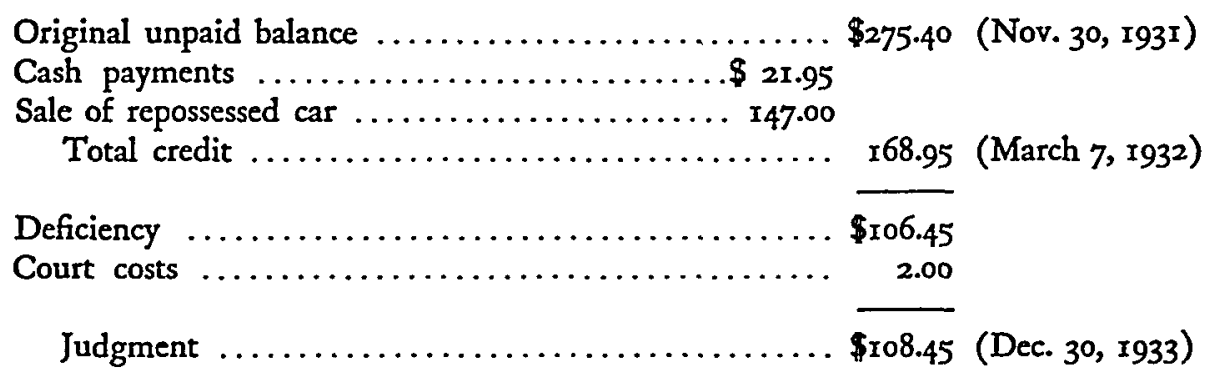

The first hearings for partial payments on these judgments were not held until May, 1934. At that time the defendant was being paid $\$ 40$ every two weeks. Payments were fixed at $\$ 2$ bi-weekly on each judgment. The court reduced his payment to $\$ 1$ on the next payday because the defendant received only $\$ 15$. The defendant 
made payments of $\$ 2$ on each account on June 12 and June 27 . On the next payday, July 9, he was laid off and payments were suspended.

The defendant was rehired in January, 1935, at an average bi-weekly wage of $\$ 50$. Immediately thereafter he applied to have his motion reinstated. He was a native American, about thirty years old. He was well dressed and seemed ashamed that it was necessary to settle his affairs in court. He said he had a wife and four children, and was also supporting his father. The Court increased his bi-weekly payments to $\$ 2.50$ on each judgment. The attorney for the instalment finance company oojected that this was too little, but the Court refused to require larger payments.

\section{Case Number 3 .}

The plaintiff was an instalment jewelry company; the defendant, a colored man, employed by a manufacturer of automobile bodies. Early in 1934, when the defendant was working steadily, a salesman for the plaintiff was selling jewelry at the factory gate each evening. Although the defendant was solicited regularly, he refused to buy anything. Finally, the salesman followed the defendant home one night and succeeded in selling him a watch for $\$ 35$ and a chain for $\$ 5$. The defendant made no down payment but contracted to pay $\$ 2.99$ a month.

After the salesman had left, the defendant discovered that the watch had been used. He forced the company to exchange it for a new one. After paying $\$ 2$ on the account, he went to a reputable jeweler and discovered that the chain for which he had paid $\$ 5$ was worth only $\$ 1.75$ at retail. He refused to pay any more, and in May, 1934, the jewelry company obtained a judgment for $\$ 38$ and $\$ 2$ court costs. Because the defendant was laid off shortly after the judgment was taken, no garnishment was issued. The defendant had a wife and six children, and the family was supported by welfare relief until October, when the defendant obtained part-time employment. The plaintiff did not garnishee the defendant's wages until January, 1935, when the defendant began to work full time. The plaintiff garnisheed and recovered \$15.I4, of which $\$ 5.50$ represented court costs, from the defendant's bi-weekly wages of $\$ 37.84$.

This garnishment brought the defendant into the Conciliation Division to arrange for partial payments. At the hearing the defendant resented having to pay much more than the watch was worth. The defendant said he would not mind so much if it were not that the plaintiff's salesman still solicited business at the factory gate.

He said he also owed $\$ 23$ to an instalment clothing company, \$9 to an instalment department store, and $\$ \mathrm{I}_{7}$ to an instalment furniture company. None of these creditors had taken judgment.

The Court was inclined to agree with the defendant's opinion of the plaintiff. But the defendant had bought the merchandise, and a judgment had been awarded to the plaintiff. Because of the circumstances, the Court limited the payment to \$2 bi=weekly. If the plaintiff should object and no other judgment should be taken, the 
rate of payment would have to be raised to the full Io per cent of the defendant's wages. The Court again requested that the plaintiff's salesmen modify their tactics.

\section{Case Number 4 .}

The defendant, a negro employee of a brass company, had bought a ring from the plaintiff, an instalment jeweler. The defendant said that he tried later to return the ring, but the plaintiff would not accept it. The plaintiff brought suit and obtained a judgment. Shortly afterward the defendant arranged for partial payments through the Conciliation Division. He was then making $\$ 12$ a week. He had a wife and two children, and he reported one other debt of $\$ 20$ due to a credit clothing company. Payments were fixed by the Court at $\$ \mathrm{x}$ a week. Twenty dollars was paid in this manner, but the defendant failed to pay on three occasions, so the plaintiff had the motion vacated, and collected $\$ 16.80$ by means of three garnishments. Only $\$ 6.30$ of this sum was credited to the account; the balance of $\$ 10.50$ was court costs.

This hearing was held at the request of the defendant and the agreement to pay $\$$ I a week through the Conciliation Division was reinstated.

\section{Case Number 5.}

The plaintiff, an instalment jeweler, took a judgment for $\$$ roo.29, including $\$ 2$ costs, against an employee of a company manufacturing automobile parts. The defendant's wife, a pretty, well-dressed woman of twenty-six, came to the Conciliation Division to find out what she could do about the judgment. Her husband was working only part time and was being paid $\$ 20$ bi-weekly. She said she had two children and that her husband owed, in addition to the judgment, $\$ 24$ to a department store, $\$ 118$ to a furniture store, and \$120 to a small loan company. Her husband owed the plaintiff for a diamond ring which she was wearing. She asked the court whether the ring was worth the purchase price of $\$ 100$.

The Court had the ring appraised by a reputable jeweler who said it had cost $\$ 15$ wholesale. The defendant's wife was told that it was unfortunate that she had not obtained this information sooner and contested the amount of the judgment. Since an appeal would be expensive, she was advised to pay the debt. She agreed and arranged to make payments of $\$ 2$ bi-weekly through the Conciliation Division.

At the hearing the Court told the plaintiff that he would like to see the case appealed, and that if he found such a case where the defendant could afford it he would suggest that an appeal be made. The plaintiff's defense was that the defendant was guilty of conversion because he gave the ring to his wife, contrary to the sales agreement.

\section{Case Number 6.}

The plaintiff, an instalment jewelry company, took a judgment against a colored man who had been employed for two years by a brass company. The defendant said that the debt was for a $\$ 42$ watch which he bought just outside the factory 
from the plaintiff's salesman. He said further that he had paid about $\$ 20$ on the watch before he defaulted. The plaintiff took a judgment against him for \$3I in August, 1934. Following the judgment, the defendant arranged for partial payments. His employer reported that the defendant's average weekly check was \$13.40 and that he frequently "lays off one or two days on own accord." But the defendant made no payments through the Conciliation Division because a few days after he made the motion he was laid off. He went on welfare relief until January, 1935, when he was rehired at $\$ 24$ a week.

At this rehearing the defendant appeared in a worn and shoddy coat. He said that, in addition to the judgment, he owed three or four instalment clothing companies and a bill for room and board. Most of the $\$ 28$ he received on January 25 had been paid toward his room and board bill and, although this hearing was held only three days after his payday, he now did not have a cent. The motion was granted. The first payment was to be made promptly on the following payday.

\section{Case Number 7 .}

Three plaintiffs, an industrial bank and two instalment jewelry companies, hàd taken judgments against the defendant, a street-car motorman. The defendant was represented at this hearing by his wife, a young, native-American woman. She said she had two children and that her husband earned \$40 bi-weekly.

The defendant had borrowed from the industrial bank and had bought the jewelry while he was working. But he had been laid off before he repaid these contracts. The defendant's wife said he had been working for the street railway for six and one-half years, that he had been laid off for three months during 1934, and that he would have to work five and one-half years longer before he would not be subject to lay-off.

The defendant's wife arranged to pay $\$ 1.5^{\circ}$ bi-weekly on each judgment. The defendant had a fourth judgment already in the Conciliation Division and the payment on that one was reduced to \$1.50.

\section{Case Number 8.}

The plaintiff was an instalment clothing company. The defendant was employed by a laundry. On October 4, 1934, the defendant bought his wife a coat and purse from the plaintiff. Two days later he lost his job. He had work during the month of November, and made some payments on the account. But he was laid off again during December and January, and was supported by welfare relief. His wife supplemented this allowance by earnings from two or three days' work each week.

On January 24, the defendant's wife, greatly agitated, came into the Conciliation Division. She had paid the plaintiff $\$ 3.50$ on January 5. Although the plaintiff had recorded this payment of $\$ 3.50$ in her account book, he had refused to subtract more than $\$ 1.50$ from the balance due. In examining her account the Court found that the plaintiff had taken a judgment in December for \$25.49, representing a balance 
due of $\$ 23.49$ and $\$ 2$ costs. In January, however, the plaintiff had taken the court costs out of the defendant's $\$ 3.5^{\circ}$ payment and refused to credit it to the account. The record of the account follows:

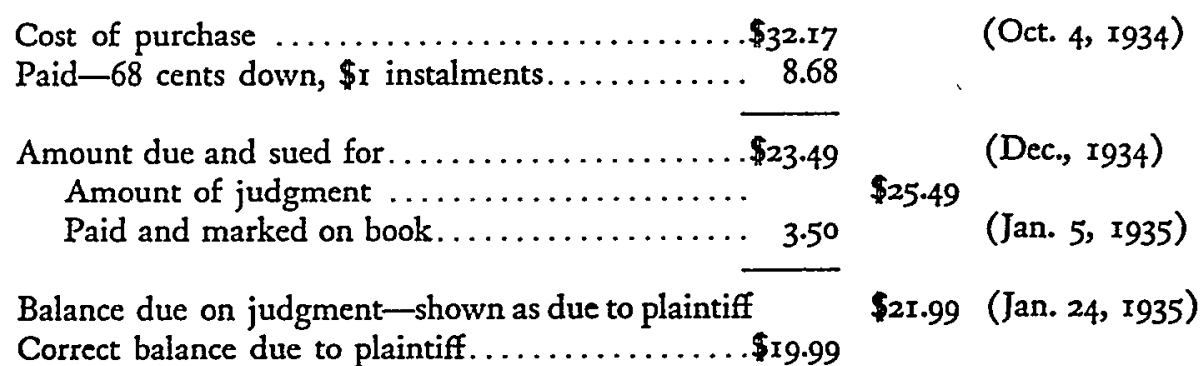

The Court immediately telephoned the plaintiff's bookkeeper, explained that court costs had apparently been charged twice on this account and directed him to correct his books. The bookkeeper replied that the entry must have been an error, and that he would correct it at once.

When the defendant returns to work he will arrange to make his payments through the Division.

\section{Case Number 9.}

The plaintiff, an instalment clothing company, had a judgment for $\$ 29.50$ against the defendant, an employee of an automobile manufacturing company. Apparently the defendant made some payments directly to the plaintiff, and then in December, r934, arranged for partial payments through the Conciliation Division. At the time of that hearing he reported that he was earning $\$ 35$ bi-weekly, and that he had a wife and two children. He said he owed three other delinquent debts; $\$ 30$ for rent, $\$ 45$ for insurance, and $\$ 215$ to a small loan company. His payment was fixed by the court, and he paid regularly.

By January, i935, the defendant had repaid $\$ 15$. But one night, at II p.m., he was aroused by a threatening "collect" telegram concerning the account. The telegram was signed by a detective agency, which, it was discovered, was not even listed in the telephone directory. A few days later the defendant reported this occurrence to the Conciliation Division. The Court told him not to worry. The plaintiff was notified to stop this practise and to credit the defendant with the cost of the wire because this use of a "collect" telegram was not legal.

\section{Case Number 10.}

The defendant, an employee of an automobile manufacturing company, had bought clothing from two instalment clothing companies several years before the date of this hearing. Both clothing companies went through bankruptcy, and the plaintiff, who had been associated with both companies, bought the accounts of each for 5 cents on the dollar. In May, 1934, the plaintiff sued the defendant for one of 
these accounts and got a judgment for $\$ 35.50$. In June the defendant arranged to make partial payments directly to the plaintiff.

The defendant made payments regularly when employed. When the amount of the judgment had been repaid, the plaintiff told him that his payments had been credited to the second account and that he must now pay on the judgment. On January 4 the defendant received no pay for the previous two weeks. His wife telephoned the plaintiff and was told to wait until he was paid. But before he reccived his next bi-weekly wages, the plaintiff garnisheed.

The defendant came to court to get the garnishment released and to arrange for partial payments through the Division. He was a neatly-dressed native American, about twenty-seven years old. He said his wife was about to have a baby, their second child. He could ill afford to lose time from work, and she would have represented him if it were not for her condition.

The plaintiff claimed that the defendant had arranged with him to pay off the open account first. The Court ruled that this use of the judgment as a lever was not allowable, and released the garnishment. The defendant paid \$1.75 to the court in satisfaction of the judgment.

After the hearing the defendant said he had little confidence in the plaintiff, and he hoped the plaintiff would get a judgment for the other account so that he could pay through the Division. This would cost an additional $\$ 2$ for the judgment, but he knew he would receive fair treatment in the court. The defendant also was wondering whether, after the dispute, the plaintiff would credit him with $\$ 7.05$ which he had paid the company but for which he had no receipts.

\section{Case Number 1 .}

The plaintiff, an automobile finance company, had a judgment for \$177 against the defendant, who had been employed in the same automobile manufacturing company's plant for two years. Early in 1934, when the defendant was working steadily, he bought a second-hand car. He had the car just seven months. In the summer he was laid off and could no longer continue his payments. He returned the car and signed a repossession. He had no work until January, 1935. As soon as he was reëmployed the finance company took a deficiency judgment for the balance due and garnisheed his first pay. As a result of the garnishment action he was discharged.

The defendant was greatly excited when he came into the Division. He was a thin young American. He said he had a wife and three children, and that he had never had any previous dealings with the law. He gratefully obtained a letter to his employer, in which the Court stated that garnishment would not happen again as the bearer would make partial payments through the Division and pay off this bill.

While he was waiting for the letter he said that the amount of the judgment seemed very large to him. After the repossession of the car the debt was only \$15 less 
than the amount he had originally owed the finance company. Of course there were interest charges, and the car apparently was resold for a small sum.

The following day the defendant returned to the court to say that the letter had done very little good. His employer had said that there might be a place for him after a month or six weeks. He wandered aimlessly around the court room for about an hour, as if he did not know what to do next. Finally, appearing completely dejected, he walked out of the Division.

When he is reëmployed he will have to have his motion reinstated and start making payments.

\section{Case Number 12.}

In December, 1934, the plaintiff, an instalment finance company, had taken a judgment for $\$ 40$ against the defendant, a thirty-five-year-old colored employee of a rubber goods manufacturing company. The debt was for a deficiency resulting from the repossession and sale of a second-hand car which the plaintiff had financed.

The defendant had reduced the judgment to $\$ 27$ by instalment payments to the plaintiff. But in January, 1935, he came to the Conciliation Division to arrange a motion for partial payments. He was greatly excited. Although he was wearing a ragged coat, he said he had property, and was afraid that the plaintiff would attach it. The "property" was a I934 Studebaker which he was buying on the instalment plan. His payments were up-to-date, but he still owed $\$ 800$.

He said he was receiving $\$ 45$ bi-weekly and that his last pay was $\$ 54.70$. He stated that he was paying off his other old debts, but still owed a balance of $\$$ I7 for rent and a similar amount for groceries. He had a wife and one child.

He arranged to pay the judgment through the Division, which would prevent garnishment but would not interfere with a property execution.

\section{Case Number 13.}

The plaintiff, an instalment furniture company, had taken a judgment against the defendant, who was employed by a bakery. After the judgment was taken, the defendant made regular payments to the plaintiff. In January, 1935, his wages were cut from $\$ 29$ to $\$ 21$ a week, and he applied to the plaintiff to have his rate of payment reduced. The plaintiff refused and threatened to attach the defendant's furniture.

The defendant's wife, a neatly-dressed woman about thirty years old, came to the Conciliation Division. By questioning her the Court discovered that the defendant had two accounts with the furniture company. The company had taken judgment for the balance due on the first account and was entitled to repossess only the furniture-a very small proportion of the total-bought on the second account. The defendant's wife was advised to let the plaintiff take the furniture, but to be sure that he made no mistake and removed some pieces bought on the first account.

Before leaving the Division, the defendant's wife made a motion for partial payment to prevent a garnishment being issued on the judgment. 
Case Number 14.

In March, 1934, the plaintiff, an instalment furniture company, had obtained a judgment for $\$ 86$ against the defendant, an employee of an automobile body manufacturer. At that time, the defendant's employer reported his average earnings to be $\$ 32$ bi-weekly. Payments were fixed by the Conciliation Division, and from April

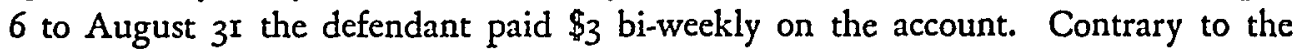
usual practice, when he received a "short" pay he did not seek a reduction in his payment, but asked for a suspension and then doubled his next payment. He was laid off in September, but returned to work in November. His employer reported. that he was averaging $\$ 45$ bi-weekly. His motion for partial payments was reinstated and his rate of payment set at $\$ 4$. He paid regularly, but his two January checks were for $\$ 30$ each, and he paid only $\$ 3$ on these paydays.

The case was reopened at the request of the wife of the defendant. She was about twenty-eight years old and pleasant-appearing in spite of a profusion of curls, gold teeth, and a veil. She reported that they owed the plaintiff $\$ 80$ on another furniture account, and that repossession of both sets of furniture had been threatened because the second account had not been paid. In addition to sustaining two children, they had reduced their debts between April and December as follows:

\begin{tabular}{|c|c|c|c|c|c|}
\hline & $\begin{array}{c}\text { Furniture } \\
\text { No.I } \\
\text { (judgment) }\end{array}$ & $\begin{array}{c}\text { Furniture } \\
\text { No.2 }\end{array}$ & Groceries & Rent & Doctor \\
\hline April & .. $\$ 86$ & $\$ 83$ & $\$ 50$ & $\$ 60$ & $\$ 16$ \\
\hline December & 40 & 80 & 25 & 60 & $x 6$ \\
\hline
\end{tabular}

The defendant expected larger pay-checks in February, and his wife offered to pay $\$ 5$ every two weeks, in addition to making up the $\$ 2$ which she had not paid during the preceding "short" weeks, if the Court would assure her that their furniture would not be removed. She was told to continue the payments as previously agreed. The Court telephoned the plaintiff, told him that she was paying regularly through the Division, and asked him to wait until the judgment was paid off before he attempted to collect on the second account. The plaintiff's representative replied that there must have been some mistake, and that the company would neither threaten her again nor take her furniture.

\section{Case Number 15.}

The defendant, who was employed by an automobile manufacturing company, had made a purchase from the plaintiff, an instalment furniture company. The defendant had a wife and five children. He was laid off in September, 1934, and he went on the welfare roll. His payments were defaulted, and in December, 1934, the plaintiff took a judgment for $\$ 32$.

The defendant was rehired in January, 1935, at an average bi-weekly wage of $\$ 42$. A week after he went back to work he came into the Division to arrange for partial 
payments. He reported other debts of $\$ 35$ for groceries, and $\$ 20$ for gas and electricity.

At the hearing he was particularly worried by the amount of the judgment. Apparently he had made two purchases from the furniture company on the same account. He said he owed the furniture company more than $\$ 32$ and was afraid that, in spite of his payments through the Division, they would remove his furniture. The Court told him that they might do so-that they probably had a legal right to take the furniture-but that if the company tried it or threatened it, while he was making regular payments, he should come back to the Division, and the Court would try to prevent it.

The motion for partial payments was granted.

Case Number 16.

On January 4, r935, the plaintiff, a shop selling electrical goods on the instalment plan, took a judgment for $\$ 54.40$ against an employee of an automobile manufacturing company. In January, I934, the defendant was working steadily, and a salesman friend persuaded him, in spite of his wife's objections, to buy a $\$$ I24 radio from the plaintiff. He paid $\$ 2 \mathrm{I}$ down and $\$ 7.80$ a month until he was laid off in the early summer. He had some work in the fall but did not make any payments on the radio because of unforseen medical expenses-one of their children had an abscess. He returned to regular work in December, 1934, at an average wage of $\$ 60$ bi-weekly.

When the judgment was taken the defendant was working in the day time, so his wife attended to the matter. She was most perplexed by the amount of the judgment, $\$ 54.40$, because she figured her balance due to be $\$ 60.18$. The total of her bill was $\$ 127.18$ - the $\$ 3.18$ was for repairs-and they had paid $\$ 67$. She went to the shop and pointed out their error. They informed her that she was correct but that they had taken the judgment for less than the full balance so that they could still take the radio back -even after they had garnisheed her husband's wages several times. They had taken their judgment for the balance due as of the date of judgment and one monthly payment was not yet due.

She did not understand this and appeared in the Division for her hearing wondering whether the shop could do this if she paid through the Division. The Court told her that the shop could legally replevin the radio whether she paid through the Division or not, but that if she would pay $\$ 6$ through the court each payday he would attend to the matter. He requested the shop over the telephone, not to take the radio or threaten her while the payments were continued, and told her to return to the Division immediately if they did either.

She was very neat, white, apparently American-born and about twenty-eight years old. After her worry was settled she smiled delightfully, and said that she had four children and owed, in addition to the radio debt, $\$ 33$ to the doctor, $\$ 15$ on a loan, and $\$ 57$ on her furniture. 


\section{Case Number I7.}

The plaintiff, an instalment department store, took a judgment for $\$ 36.40$ for merchandise against the defendant, who was employed in an automobile manufacturing company's plant. The plaintiff garnisheed the defendant's wages twice. As a result of these actions, the defendant made a motion for partial payments. The defendant said his wage was $\$ 53.50$ every two weeks. He did not mention unemployment, but claimed to be supporting his brother and sister. He reported three other unpaid debts totaling $\$ 580$.

At the hearing he arranged to pay $\$ 5$ each payday on this debt, and stated that the reason for his having to arrange the matter through the Division was that the plaintiff had refused to accept $\$ 5$ bi-weekly payments from him when he offered to settle directly.

\section{Case Number 18.}

The plaintiff, an instalment finance company, had taken a judgment for $\$ 17 \mathrm{r}$ against the defendant, a forty-year-old street-car motorman. The defendant was paid $\$ 60$ bi-weekly. He had a wife and six children. He had just been through bankruptcy, but reported that he owed, in addition to the finance company's judgment, $\$ 202, \$ 187$, and $\$ 157$, respectively, to three instalment furniture companies. He was paying $\$ 2$ a week on one account and $\$ 3$ a week on the other two.

Following his bankruptcy, and while he was paying the furniture companies, the defendant purchased an electric refrigerator for $\$ 182$ and agreed to pay the plaintiff company, which financed the sale, at the rate of \$I4 a week. He defailted almost immediately and as a result the judgment was taken. There was no.evidence that he had been unemployed.

At the hearing the Court reprimanded the defendant for making such a purchase while still so heavily in debt and after going through bankruptcy. His only reply was that his wife had insisted she had to have the refrigerator. The motion was granted, and the defendant made his first payment on the day of the hearing.

\section{Case Number 19.}

A carpet company, selling on the instalment plan principally to negroes, was the plaintiff in this action to collect \$25.I9 from a colored employee of an automobile body manufacturing company. The defendant bought a carpet from the plaintiff in April, 1934, for $\$ 31.75$, making a down payment of $\$ 2.15$. He paid $\$ 8.91$ on the account during the next few weeks, but failed to continue his payments thereafter. In August, the carpet company took judgment for the debt and proceeded to garnishee his wages. Garnishment was unsuccessful because the defendant had been laid off, which probably also accounted for his failure to make payments. Between August and December, however, the defendant paid $\$ 2$ additional on the account.

The defendant was reëmployed in December, and by agreement with the carpet company used his first pay to reduce his debt to his landlord. He said he promised 
to pay the company something on his second payday. But before he received his second pay, the carpet company garnisheed. The company received $\$ 7.26$ of $\$ 18.15$ due to the defendant for services. Of the $\$ 7.26$, however, $\$ 2.50$ represented cost of garnishment. At the date of the hearing the account stood as follows:

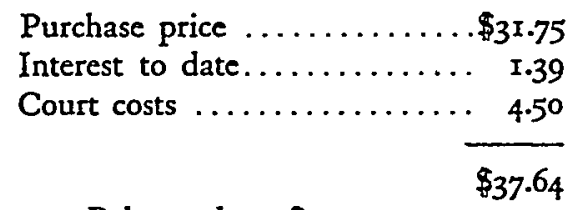

Balance due- $\$ 17 \cdot 32$.

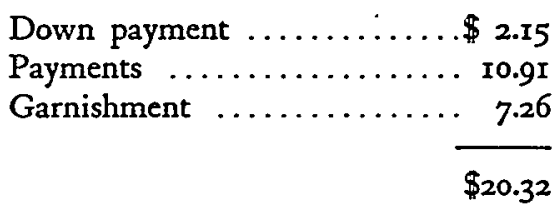

The motion was granted.

\section{Case Number 20.}

Two plaintiffs, an industrial bank and an instalment carpet company, had taken judgments in August and December, 1934, respectively, against the defendant, a colored employee of an automobile manufacturer. In January, 1935, the defendant made a motion for partial payments on both judgments. The defendant knew that his employer's policy was to discharge an employee for having a garnishment action, but he did not appear for his hearings. The bank's attorney was present. The Court started to dismiss the motions. But the attorney asked for a delay; saying to wait, that he remembered the defendant and would like to give him a chance. The Court consented and told him to be sure to notify the defendant immediately, for the other plaintiff's policy was always to garnishee.

\section{Case Number 21.}

Three plaintiffs, two grocers and an instalment carpet company, obtained judgments in March, 1934, for $\$ 8 \mathrm{r}, \$ 40$, and $\$ 34$, respectively, against the defendant, who was an old colored man employed by the city. Within the same month the defendant arranged for partial payments of $\$$ I a week on each of these three judgments. Although he was employed, he did not pay regularly. In October the fourth plaintiff, an instalment clothing company, obtained judgment against the defendant. In January, I935, the fifth plaintiff, an instalment jewelry company, took a judgment against the defendant. Meanwhile, the motions for partial payments on the first three judgments had been vacated because of the irregularity of the defendant's payments.

At the present hearing, in January, 1935, the defendant appeared, wearing ragged clothes. He reported that he had a wife and four children, and that his wage was $\$ 33.75$ a week. He had brought the two grocers' judgments for reinstatement, and made new motions on the instalment clothing and jewelry companies' judgments. The defendant failed to remember the judgment of the carpet company.

The Court fixed payments at $\$$ a week on each judgment, and admonished the grocer who was present at the hearing to garnishee in the event the defendant de- 
faulted on any payment. The Court severely reprimanded the defendant for purchasing jewelry when still owing so many other debts. The Court's last words to the defendant directed him to arrange immediately for the reinstatement of the carpet company's judgment.

A week later the defendant reappeared to have the carpet company's judgment reinstated. Hi said he had not done this before because he had talked to this plaintiff and had promised to pay something each week direct. The defendant admitted that this debt was eight years old.

\section{Case Number 22.}

The plaintiff was an instalment jeweler who, in 1933 , had sold a $\$ 57$ watch to the defendant, a colored man employed by an automobile manufacturing company. The defendant was thirty years old and had a wife and two children. He was unemployed for several months in the latter part of 1933 and defaulted his payments. The jeweler obtained judgment for $\$ 49$ in March, I934. A hearing was held to arrange partial payments on the judgment. The borrower's wage then averaged \$50 each hi-weekly period. Payments on the judgment were fixed at $\$ 5$ to be made on each payday. In this manner the defendant reduced the judgment to $\$ 34$. Subsequently, in the summer of 1934, he was laid off again, and payments were suspended. He was reëmployed in January, 1935. The present hearing was held to reinstate his payments.

In March, 1934, he had reported that, in addition to the judgment, he owed $\$ 36$ to another credit jeweler, and $\$ 10$ and $\$ 30$ to two instalment clothing companies. In January, r935, he said that the debt to the second instalment clothing company was now $\$ 36$, that he owed $\$ 65$ for delinquent rent and several other debts. The Court chided him upon his numerous credit purchases and pointed out that the cost of credit was necessarily included in the price. The defendant replied that he should not have bought the jewelry, but that it was impossible for any colored person to buy clothing except on credit. He was trying to pay $\$ 5$ every two weeks on the largest clothing account and $\$ 4$ bi-weekly on the debt for rent. He said he just couldn't save, and that he had only four and one-half months' work last year. He was always trying to pay all his delinquent bills, but managed only to pay some of his current expenses.

The motion was reinstated at the previous rate of payment.

\section{Case Number 23.}

Two plaintiffs, an instalment jewelry company and an instalment department store, had taken judgments in May and September, x934, respectively, against the defendant, a colored man employed by a local branch of a nation-wide business. In January, I935, the defendant made motions for partial payments.

At this hearing the defendant said that both the plaintiffs and two other creditors, another instalment jeweler, and an instalment furniture company, had all garnisheed 
his wages. He reported that he worked on a piece-work basis and his earnings averaged $\$ 20$ a week. The week before last a garnishment had taken $\$ 8$ out of his $\$ 20$ pay. Last week his pay was but $\$$ Io, of which $\$ 4$ was taken by a garnishment.

$\mathrm{He}$ arranged to pay \$r.50 a week on each judgment, beginning the following payday. He was urged to arrange partial payments on the other two judgments.

\section{Case Number 24.}

The plaintiff, an instalment jewelry company, took a judgment against the defendant, a Polish employee who had worked twelve years for an automobile manufacturing company. About the same time the defendant received a letter from an instalment clothing company threatening a suit for an account.

The defendant's wife came into court. She could speak very little English, but spoke in Polish with one of the court clerks. She made a motion for partial payments on the judgment, and was told to go to the clothing company and offer to make payments directly to them to avoid a second judgment.

\section{Case Number 25.}

The two plaintiffs were instalment merchants: a carpet company and a department store. The defendant was employed by a rubber company. He was a colored man about twenty-five years old, and appeared in court in a bright green sweater. He said he had left Georgia in I93I and worked for an Akron rubber company for a year. In 1932 he heard through a relative of a job which he now holds. He went to Detroit, got the job, and worked steadily. His average wage was $\$ 42$ bi-weekly. He was married in 1933 and now has one child.

In June, I934, he bought window curtains and rugs from the first plaintiff. He made some irregular payments on the account and then defaulted. The carpet company took a judgment for $\$ 46$ in August. In December, I934, he bought some clothing from the second plaintiff. He defaulted on his payments and the department store took a judgment for $\$ 46$ the same month.

In the meantime an instalment clothing company had twice sent a salesman to the defendant's home to solicit business. On January 5 , 1935, in spite of the two judgments, he made the following purchases:

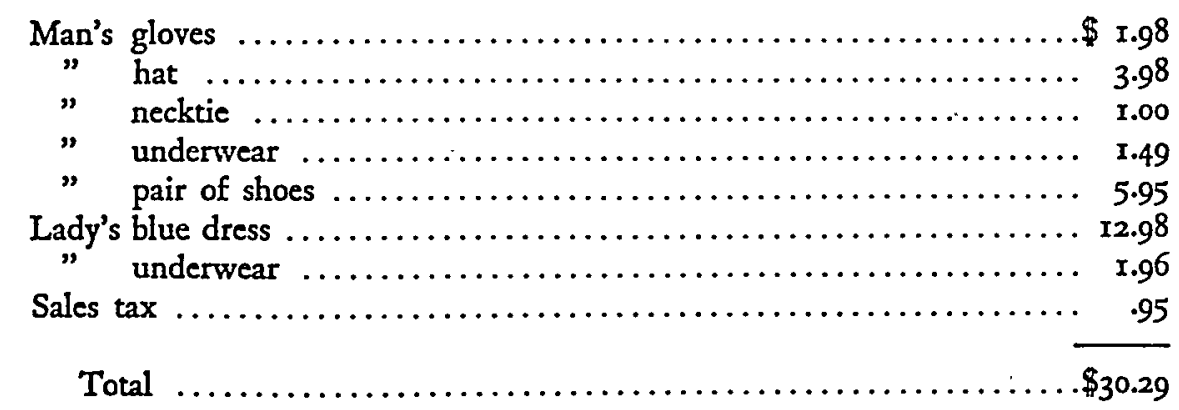


He paid 88 cents down and promised to pay $\$ 3$ a week. He said that so far he had paid the company only $\$ 2$ which he did on January ro. He was wearing the hat, necktie, and shoes. The hat was probably worth 98 cents; the necktie, badly frayed; and the shoes seemed as if a good rain would reduce them to pulp.

Shortly after he made this purchase the department store garnisheed his wages. The carpet company did not garnishee, but told him to arrange for partial payments through the Division. He came into the Division to make motions on both judgments. He did not mention his recent purchase of clothing until the Court asked him if he owed anything to certain specific clothing companies. Whether he had any other debts was not determined.

His motions were granted. 